\title{
Ślady wilczych zębów - na pograniczu Czech, Niemiec i Polski
}

Pogranicze czesko-polsko-niemieckie to terytorium złowrogie. Pełne napięć, konfliktów, nikczemności, słabo zidentyfikowane tożsamościowo - ni czeskie, ni polskie, ni niemieckie. Wojna nie tylko pozostawiła tu swoje piętno, zmieniła wielokulturową strukturę społeczną i zdewastowała mikroświat na niej oparty, lecz bynajmniej nie zakończyła się wraz z bezwarunkową kapitulacją III Rzeszy. Hitlerowska partyzantka - werwolf znalazła na tym terenie dogodne warunki dla swego funkcjonowania, a ponadto przynajmniej do czerwca 1945 roku działały tam, dowodzone przez ostatniego naczelnego dowódcę wojsk lądowych III Rzeszy feldmarszałka Ferdinanda Schörnera, jednostki nieuznające rozkazu o złożeniu broni. Ogółem na terenie Czechosłowacji przeszkolono około 1100 wilkołaków i zorganizowano kilka tysięcy podziemnych magazynów broni i zaopatrzenia. Dywersja prowadzona była nie tylko na terenach pogranicznych, choć rzeczywiście tam najbardziej dawała się nowym władzom we znaki. Wydarzenia, takie jak: wykolejenie $\mathrm{w}$ Chomutovie pociągu z czeskimi partyzantami, rajd przeciwpartyzanckiej kompanii SS z Liberca w okolice miasta bawarskiego Cham czy zamach na posterunek policji we Freudenthal (Bruntál) we wschodniej części Kraju Sudeckiego - to nie jedyne przykłady świadczące o niespokojnym charakterze powojennego porządku${ }^{1}$. Relacje czesko-niemieckie determinowane były postawą Niemców sudeckich w okresie poprzedzającym dyktat monachijski oraz podczas trwania niechlubnego Protektoratu Czech i Moraw. Po tych doświadczeniach zarówno Czesi nie widzieli swych niegdysiejszych współobywateli w granicach nowej Czechosłowacji, jak i ludność niemiecka (niezależnie od poglądów politycznych) liczyła na to, że Sudety pozostaną w strukturze powojennych Wielkich Niemiec. Antyniemiecka akcja wysiedleńcza, nosząca

* Uniwersytet Kazimierza Wielkiego w Bydgoszczy.

1 Szerzej na temat działalności Werwolfu na terenie Czech i Kraju Sudeckiego zob. Perry Biddiscombe, Werwolf. Brunatni pogrobowcy Hitlera, przeł. Sławomir Kędzierski, Wydawnictwo Czerwone i Czarne, Warszawa 2013, s. 319-343. 
w literaturze przedmiotu nazwę odsun, była radykalna, natychmiastowa i przeprowadzona w niedającej się wytłumaczyć innymi niż odwetowe racje, procedurze zbiorowej odpowiedzialności ${ }^{2}$ Zarysowane wyżej tło historyczne tworzyło aurę powstałej w 1972 roku powieści Vladimíra Körnera Zánik samoty Berhof, której akcja toczyła się w Dolinie Kłodzkiej po czechosłowackiej stronie granicy bezpośrednio po wojnie. O tej historii Körner myślał już od dawna. Początkowo miała nazywać się po prostu Samota Berhof, a pierwsze przymiarki do jej kinowej reprezentacji czynił jeszcze przed normalizacją z Františkiem Vlačílem i operatorem Františkiem Uldrichem, z którymi w tym czasie pracował nad adaptacją swego utworu Adelheid. Wytypowali oni nawet kandydata do głównej roli męskiej - porucznika. W późniejszym filmie Jiř́iego Svobody zagrał go Milan Kňažko, jednak pierwotnie Körner tworzył tę postać z myślą o Petrze Čepku. Po inwazji wojsk Układu Warszawskiego filmowa nowela przybrała postać minipowieści, już zatytułowanej Zánik Samoty Berhof i przyjętej dość niechętnie przez środowisko normalizacyjnych krytyków. Przykładowo na łamach dziennika „Večerni Praha” znany publicysta Fedor Soldan napisał: „młody, nikomu nie znany autor Vladimír Körner w nieskrywany sposób kibicuje faszystowskim zbrodniarzom" ${ }^{3}$. Pomimo cenzuralnej niechęci opublikowana historia nadal budziła zainteresowanie czeskich filmowców. W roku 1980, po nakręceniu na podstawie scenariusza Körnera dramatu Cukrová bouda, o Zániku... jako kolejnym swym zamierzeniu wspominał w jednym z wywiadów Karel Kachyňa ${ }^{4}$. W roku 1976 ukazał się nakładem wydawnictwa "Czytelnik" polski przekład dokonany przez Andrzeja Piotrowskiego - Zagłada Poziomkowego Dworu ${ }^{5}$. Doczekał się on kilku, równie wstrzemięźliwych recenzyjnych wzmianek w prasie ${ }^{6}$. Warto przywołać jedną z nich, napisaną przez opozycyjnego krytyka i literaturoznawcę Jana Walca, bowiem jak

2 Piotr M. Majewski, "Niemcy sudeccy” 1848-1948. Historia pewnego nacjonalizmu, Wydawnictwa Uniwersytetu Warszawskiego, Warszawa 2007, s. 428-456.

${ }^{3}$ Słowa tej recenzji na długo zapadły Körnerowi w pamięć. Zacytował je po latach w wywiadzie udzielonym „Domažlickému deníkovi” w numerze z 28 kwietnia 2005 roku, zob. Vladimír Körner, Rozhovory 1964-2009, Nakladatelství Dauphin, Praha 2009, s. 178179. Jeżeli nie zaznaczono inaczej tłumaczeń z języka czeskiego dokonał autor artykułu.

${ }^{4}$ Był to wspólny wywiad Karela Kachyňy i Vladimíra Körnera opublikowany w tygodniku „Květy” z 15 października 1980 roku, zob. tamże, s. 17.

${ }_{5}$ Vladimír Körner, Zagłada Poziomkowego Dworu, przeł. Andrzej Piotrowski, Wydawnictwo Czytelnik, Warszawa 1976.

${ }^{6}$ Zob. Awar, [Edwarda Opoczyńska], Recenzje. Zagłada Poziomkowego Dworu, „Wiadomości” 1977, nr 11, s. 15; Anna Bluszcz, Zagłada Poziomkowego Dworu, „Głos Ludu” 1979, nr 138, s. 5 . 
w zwierciadle odbija ona wszystkie różnice kulturowe w postrzeganiu historii XX wieku przez Czechów i Polaków:

\begin{abstract}
Akcja powieści toczy się w Sudetach bezpośrednio po zakończeniu ostatniej wojny i tyczy bardzo skomplikowanych zagadnień czesko-niemieckich. Wyczuwa się jednak na pierwszy rzut oka jej literackość w złym sensie tego słowa; urodzony w 1939 roku autor nie przeżył opisywanych czasów w sposób świadomy i posługuje się często literackimi schematami, jakkolwiek - co również w książce widoczne - chciałby próbować schematy te przełamywać. Wynika z tej powieści, że Niemcy mają do sprawy Niemców Sudeckich stosunek ciągle nacechowany pewną nerwowością w czym nie ma zresztą nic zaskakującego. Körner w swojej książce próbuje pokazać, że granica między dobrem a złem nie w każdym przypadku musi się pokrywać z granica między Czechami a Niemcami, tym bardziej, że mieszkańcy Sudetów nie zawsze do końca wiedzieli, do jakiego należą narodu ${ }^{7}$.
\end{abstract}

Vladimír Körner w Czechach ceniony był jako twórca powieści historycznych dotykających zarówno odległych wydarzeń z przeszłości, np. Údolí včel (Dolina pszczót) i Písečná kosa (Piaszczysta mierzeja), których akcja osadzona była $w$ realiach średniowiecza, jak i niedawno minionych, które można było konfrontować z pamięcią żyjących jeszcze pokoleń. Te ostatnie reprezentowane były przede wszystkim przez dwa tytuły: Adelheid oraz właśnie Zánik samoty Berhof i dotykały skomplikowanych relacji czesko-niemieckich ${ }^{8}$, które w oficjalnym dyskursie prawie nie istniały lub przedstawiane były w sposób uproszczony i schematyczny ${ }^{9}$. Na

7 Jan Walc, Małe recenzje. Zagłada Poziomkowego Dworu, „Literatura na Świecie” 1977, nr 6, s. 380 .

${ }^{8}$ Niezwykle interesująco pisarstwo Vladimíra Körnera i jego ekranowe przykłady z uwzględnieniem utworów powstałych po 1989 roku omówił Libor Martinek. Oprócz wspomnianych w niniejszym tekście ekranizacji powieści Adelheid i Zánik samoty Berhof zanalizował on także konteksty relacji czesko-niemieckich na przykładzie filmowych wersji książek Der Lebensborn - Pramen života (2000) i Krev zmizelého (2005) - obie adaptacje zostały dokonane przez Milana Cieslara, zob. Libor Martinek, Kwestia czesko-niemiecka w adaptacjach filmowych dzieł literackich Vladimíra Körnera (z języka czeskiego przełożyli Leszek Engelking i Elżbieta Wandycz), [w:] Przyszłość w kinie Europy Środkowej i Wschodniej po roku 1989. Zbiór materiałów z konferencji 8-10 listopada 2007 roku w Poznaniu, red. Bogusława Bakuła, Monika Talarczyk-Gubała, Wydawnictwo WiS, Poznań 2008, s. 157-171.

9 Zofia Tarajło-Lipowska, Historia literatury czeskiej, Zakład Narodowy im. Ossolińskich, Wrocław 2010, s. 445. Problematyka niemiecka w kontekście odsunu znalazła swoją reprezentację dopiero w wydanej w 2001 roku powieści Josefa Urbana Habermannưv mlyn, którą w 2010 roku przeniósł na ekran Juraj Herz. O okolicznościach realizacji tego filmu zob. Juraj Herz, Autopsie (pitva režiséra), Mladá fronta, Praha 2015, s. 454-461; Dana Čermáková, Karel Roden, Nakladatelství Imagination of People, Praha 2013, s. 143-148. Josef Urban temat ten podniósł także w swym późniejszym utworze 7 dní hř́ichư: Román o zradĕ, lásce, prátelstuí, który został zekranizowany w roku 2012 przez Jiříego Chlumský'ego. 
niespełna pięciu arkuszach wydawniczych (polska edycja miała format kieszonkowy i liczyła 147 stron) Körner utkał opowieść dziejącą się latem 1945 roku. Leżący na odludziu zajazd turystyczny Berhof, zamieszkały przez gospodarza Alfreda Habigera, przygotowującego się do pochowania zmarłej żony, jego córkę Ulrykę oraz Tyldę - niegdysiejszą prostytutkę, ukrywającą się przed gniewem czeskich pobratymców w górskiej samotni, nawiedzają bestie. Oczywiście bestie w ludzkiej skórze - esesman Karleman, zakonnica Salome i umierający nastolatek Erich Hell - post-hitlerowscy partyzanci, „wilkołaki”. Są uciekinierami, ale szlak ich ucieczki znaczony ukrytymi w górskich ostępach składami amunicji, zakonspirowanymi w miasteczkach punktami kontaktowymi jest krwawy i nacechowany okrucieństwem. Mordują bezbronnego sąsiada Berhofu Floriana, z rąk Karlemana ginie posterunkowy Łasica - zresztą Bóg raczy wiedzieć, ile ofiar ma on już na sumieniu. Szczególną figurę narracyjną tworzy Ulryka, córka Habigera, nastolatka, której dotychczasowym życiowym stygmatem były rodzinne nieszczęścia - okrutny, nadużywający przemocy ojciec, niepotrafiąca obronić córki słaba i podległa woli Habigera matka, bezalternatywna egzystencja w miejscu, które wydawało się całkowicie zapomniane przez Boga. Motywy Ulryki nie są jednoznaczne - swoiście definiowana uczciwość i współczucie każą jej z takim samym przejęciem zająć się umierającym wilkołakiem Erichem, jak i doprowadzić do unicestwienia wszystkiego i wszystkich w mikroświecie samotni Berhof. Świat zewnętrzny reprezentuje porucznik czechosłowackiej armii dowodzący zarówno siłami bezpieczeństwa, jak i instalującą się prowincjonalną postwojenną administracją. Jest on oczytany, wykształcony, posługuje się z taką samą łatwością cytatami z Goethego, jak i klawiszami kościelnych organów. Reprezentuje instytucjonalną przemoc i pomimo towarzyszącego mu humanistycznego niepokoju nie waha się z niej skorzystać.

Niemal wszystkie opowiadania i powieści Körnera pisane były z uwzględnieniem filmowej wrażliwości ich autora. Nic w tym dziwnego - po ukończeniu scenariopisarstwa w 1963 roku w klasie Františka A. Dvořáka na FAMU zaczął pracować w wytwórni na Barrandovie jako dramaturg, tworząc lub współtworząc realizacyjne skrypty do wielu celuloidowych projektów ${ }^{10}$. Kiedy w pierwszej połowie lat 80 . XX wieku rozpoczęto zdjęcia do Zániku samoty Berhof, był jednym z najbardziej rozpoznawalnych scenarzystów czechosłowackiej kinematografii, a także

10 Šárka Bartošková, Luboš Bartošek, Filmové profilý. Českoslovenští scenáristé, režiséři, kameramani, hudební skladatelé a architekti hraných filmů, Československý filmový ústav, Praha 1986, s. 200-201. 
gorącym orędownikiem filmowej polsko-czechosłowackiej współpracy. Właśnie ta ekranizacja okazała się znakomitym przykładem transnarodowego filmowego działania. Czeska wersja tytułowa brzmiała jak literacki oryginał Zánik samoty Berhof, zaś w polskich kinach obraz prezentowany był jako Ślady wilczych zębów. Nie była to jedyna adaptacyjna modyfikacja. Jiř́ Svoboda, który oprócz reżyserii także współtworzył scenariusz, oczywiście nie wyeliminował instrumentarium grozy, ale wspólnie z dramaturgiem Karlem Copem stworzył pierwszą wersję noweli filmowej, w której znalazły się nieobecne w powieści Körnera elementy. Były to: wzmocnienie figury zakonnicy Salome pokazanej jako centralna postać dramatu, usunięcie ze struktury opowiadania dwuznacznego esesmana Karlemana i wprowadzenie dwóch młodych wilkołaków Unkasa i Detleva, erotyczne napięcie między nimi a zakonnicą Salome, inna koncepcja postaci Habigera, któremu dopisano determinację w konsekwencji popychającą go do przemocy oraz odmienne zakończenie, choć mieszczące się w paradygmacie literackiego pierwowzoru. Körner nie do końca był zadowolony z takich rozstrzygnięć, ale nie protestował. Cenił Svobodę za profesjonalizm, sposoby ujarzmiania filmowej materii, a po premierze filmu oświadczył nawet:

Udało mu się $\mathrm{w}$ sposób nieprawdopodobny oddać zarówno atmosferę przestrzeni granicznej, jak i tytułowego odludzia. Głównie od momentu gdy do Berhofu przybywa strażnik Łasica. Jest to piętnaście minut czystego kina, które zapierają dech w piersi nawet autorowi powieści. Od lat tworzę filmowe historie, ale takich doznań miałem niewiele $^{11}$.

Realia filmowego Kolštejna odnalazła ekipa realizacyjna nie w przygranicznych Sudetach, ale w znajdującym się godzinę drogi od Pragi, niewielkim miasteczku kraju środkowoczeskiego o nazwie Nový Knín. Ośrodek ten był wiekowy, bowiem jego początki sięgały edyktu królewskiego z 1331 roku nadającego mu prawa miejskie, ale w drugiej połowie XX wieku raczej niezbyt dynamiczny, zaś jego mieszkańcy, jak napisał polski dziennikarz Janusz Latoszek, który towarzyszył filmowcom, „od wielu lat wiedli życie pełne monotonii i prowincjonalnej codzienności"12.

${ }^{11}$ Helena Hejčová, Variace na jedno téma /hovoř́me se scenařistou Vladímirem Körnerem/, „Kino” 1984, nr 16, s. 7-8. Fragment tego wywiadu w tłumaczeniu Hanny Smolińskiej opublikowany został także w polskiej prasie filmowej, zob. Ślady wilczych zębów (opracował hs), „Filmowy Serwis Prasowy” 1985, nr 6, s. 5.

12 Janusz Latoszek, W czechosłowacko-polskiej koprodukcji. Na planie: "Zagłada Poziomkowego Dworu”, „Życie Warszawy” 1983, nr 229, s. 6. 
Pozostałe plenery, czyli około 80 procent ujęć, zdejmowane były w Polsce w Lutyni, wsi położonej nieco powyżej Lądka Zdroju, na trasie prowadzącej do znajdującej się po drugiej stronie granicy Travnej. Odpowiedzialny za scenografię Bogdan Mozer odnalazł tam „zapuszczone i poszczerbione przez czas dawne schronisko górskie”, żywcem wyjęte z kart Körnerowej powieści. Adaptacja wnętrz samotni była wspólnym dziełem ekip z Barrandova i Łodzi ${ }^{13}$. Zdjęcia rozpoczęły się 5 sierpnia, zaś zakończyły się pod koniec października 1982 roku.

Stronę czeską reprezentował drugi realizacyjno-twórczy zespół FSB kierowany przez Josefa Císařa. Inicjatywa wyszła ze strony Jiř́iego Svobody, a kierownikiem polskiej ekipy był Andrzej Reiter, reprezentujący Zespół Filmowy „Kadr”. Koprodukcja była konsekwencją dwóch przesłanek - po pierwsze wspólnego doświadczenia wojennego, po drugie wynikała z uwarunkowań produkcyjnych. W Czechach takich górskich samotni, jakie chciał Svoboda zaprezentować w diegezie filmu, można było ze świecą szukać. W trakcie realizacji, ale i w czasie promowania filmu na festiwalach oraz po pokazach premierowych prasa branżowa i informacyjna polska, czeska, słowacka wykazywała dość duże zainteresowanie postępem prac. Publikowano niepodpisane drobne wzmianki ilustrowane materiałem zdjęciowym ${ }^{14}$, sygnowane inicjałami krótkie rekomendacje, a nawet drukowano kluczowe części scenariusza $^{15}$.

Zabieg dramaturgiczny, jakim było wzmocnienie ekranowej postaci zakonnicy Salome, spowodował, iż kreująca ją Hana Brejchová stała się centralną postacią filmu. Normalizacyjna kinematografia oferowała jej w latach 70. XX wieku dość stereotypowe role kobiet dojrzałych, głównie matek, na dodatek osadzone w popularnych konwencjach, czego przykładem mogą być: Luk královny Dorotky (reż. Jan Schmidt, 1970), Slečna Golem (reż. Jaroslav Balík, 1972) czy Pod Borsucza skata (Pod Jezevčí skálou, reż. Václav Gajer, 1978). Przełomowa okazała się nawiązana w kolejnej dekadzie współpraca z Jiřím Svobodą rozpoczęta telewizyjną Jehla w 1982 roku. „W jego poważnych psychologicznych filmach poruszających moralne dylematy, odkrywała nieznane wnętrze swojego aktorstwa

13 B. Z. (Bogdan Zagroba), Wehrwolf znaczy "wilkołak". O realizacji czechosłowacko-polskiego filmu "Zagłada Poziomkowego Dworu”, "Film” 1984, nr 10, s. 10.

${ }_{14}$ Wspólnie z Czechami. Zagłada Poziomkowego Dworu, „Film” 1983, nr 48, s. 2; Ślady wilczych zębów, „Film” 1985, nr 39, s. 15; Albuk (Alojzy Bukolt), W kinie. Ślady wilczych zębów, "Gazeta Pomorska" 1986, nr 8, s. 10; J. B., Mały przewodnik kinomana, „Tygodnik Demokratyczny" 1986, nr 50, s. 13; Kronika kulturalna, „Tak i Nie” 1984, nr 18, s. 14.

15 Vladimír Körner, Jiř́i Svoboda, Zánik samoty Berhof [ukázka ze scénaře], „Film a doba” 1984, nr 2, s. 70-90. 
i nie obawiała się pokazać zmęczonej, nieupudrowanej twarzy" - napisał autor biogramu Brejchovéj w popularnym leksykonie ${ }^{16}$. Sam Svoboda posługiwał się w opisie jej emploi bardziej metaforycznymi określeniami. Wspominając jedną z najtrudniejszych scen Zániku samoty Berhof, kiedy Salome roztacza przed młodymi wilkołakami Detlevem i Unkasem wizję ucieczki, pozostawienia za sobą przeszłości i powojennego spokoju, „ma na sobie wojskowe spodnie, prosty podkoszulek, a wygląda przy tym jak Madonna"17. Partnerujący Hanie Brejchovéj Ladislav Křiváček twierdził, że powierzenie jej roli Salome było kluczem do osiągnięcia artystycznego efektu.

Była wyjątkowa, a emanowały z niej groza i strach. Nie taki prymitywny strach charakterystyczny dla męskiej przemocy, ale kobieco wyrafinowany, który do nas przenika przez znak i gest. Ci trzej młodzi aktorzy, którzy odtwarzali role nazistowskich podopiecznych dzięki niej stawali się na ekranie prawdziwi do bólu ${ }^{18}$.

Jednym z owych „trzech młodych aktorów” był, obok Vitězslava Pohanki, dla którego była to jedyna filmowa przygoda i Zbigniewa Suszyńskiego, Marek Probosz. Aktor miał już na koncie role w czternastu filmach, lecz kreacja w Śladach wilczych zębów nie tylko należała do najdojrzalszych ${ }^{19}$, lecz uczyniła go także jednym z najbardziej popularnych polskich wykonawców nad Wełtawą. Nic dziwnego, że nie umknęła recenzentom jego dezynwoltura polegająca na nagłej zmianie tempa gry, kapryśnym budowaniu nastroju, niekonsekwencji postępowania.

Pod sympatycznym zewnętrznym wyglądem Salome i racjonalnym zachowaniem wyczuwa się ukrytą grozę. Tak samo są przedstawieni jej młodzi wychowankowie, fanatyczni zabójcy, gotowi w każdej chwili do podrzynania gardeł. A przecież i oni mają chwile, kiedy zdobywają sympatię widzów bowiem twórcy rozciągają te sceny, $\mathrm{w}$ których są ponownie nastolatkami lubiącymi się śmiać, cieszyć i bawić ${ }^{20}$. s. 104.

${ }^{16}$ Miloš Fikejz, Český film. Herci a herečky / I. díl: A-K, Nakladatelství Libri, Praha 2006,

17 Adriana Šteflová, Jana Brejchová, Nakladatelství Bondy, Praha 2014, s. 109.

18 Michalina Remešová, Roman Schuster, Jana Brejchová otveřeně: Lásky mé, já stůn̆u! Strhující životní př́beh nejkrásnější české herečky a jejích mužů, Fany, Praha 2014, s. 128.

19 Ilona Łepkowska tak o nim napisała: „Jego fascynacją jest również granie. To widać. Opowiada o ostatniej roli w polsko-czeskim filmie, o pracy z Janą Brejchovą. Gdy patrzę na niego, gdy mówi, wierzę że naprawdę umierał na ekranie. Jest prawdziwy...", zob. Mam mało czasu, czyli spotkanie z Markiem Proboszem, notowała Ilona Łepkowska, "Film” 1984, nr 18, s. 19.

${ }^{20}$ Jana Bílková, Zánik samoty Berhof, „Kino” 1985, nr 5, s. 15. 
Marek Probosz na dłużej zagościł na czeskich ekranach - zagrał Rudę Aksamita w ciekawym, choć nie do końca udanym dramacie Františka Vláčila Stín kapradiny (1984) na podstawie powieści Josefa Čapka, gdzie jego partnerem ponownie był Zbigniew Suszyński ${ }^{21}$. Został także zaangażowany do filmu będącego kontynuacją współpracy ze Svobodą - Zapadlí vlastenci 1932 na podstawie powieści Josefa Kocourka. Ostatecznie powstał dwuczęściowy obraz telewizyjny zatytułowany Horečka, a partnerami Probosza byli popularni aktorzy z Barrandova - Petr Čepek, Jiří Kodet, Jiří Schmitzer i córka Jany Brejchovéj, Tereza Brodská22.

Polska premiera 29 kwietnia 1985 roku miała charakter uroczysty, a okazją do jej zorganizowania było święto narodowe ČSRS. Obecni byli dyplomaci i politycy, w tym ambasador czechosłowacki Jiří Divišs, ale także ekipa twórców i wykonawców: Jiří Svoboda, Vladimír Körner, Jana Brejchová i Ladislav Křiváček (w notatce „Trybuny Ludu” nazwany Ladislavem Crivankiem) ${ }^{23}$. Czeskie i słowackie premiery miały miejsce nieco później - w grudniu 1985 roku i, podobnie jak polski pokaz, wpisano je w cykl obchodów 40-lecia wyzwolenia Czechosłowacjii ${ }^{24}$.

Jiř́íego Svobodę zalicza się do tych reżyserów swojej generacji, którzy wybrali indywidualną drogę twórczą. Obok Karela Smyczka, Jaroslava Sokoupa, Víta Olmera był czołowym przedstawicielem pokolenia, które filmowe nauki na FAMU pobierało jeszcze przed normalizacją. Zdaniem Jana Lukeša Svoboda w latach 80. XX wieku do perfekcji doprowadził konwencję, którą można nazwać:

[...] drażniącym dramatem psychologicznym, w którym współgrają ze sobą współczesność (Dívka s mušlí, 1980; Schůzka se stíny, 1982; Skalpel, prosím, 1985) i niedawna przeszłość (Papilio, 1986; Svĕt nic neví, 1987) i niebezpiecznie zbliżają się do sytuacji skrajnych. Do najbardziej wysmakowanych, z uwagi na wyjątkowe zdjęcia, projektów należy naturalistyczna opowieść z czeskiego powojennego pogranicza "Zánik samoty Berhof" $[\ldots]^{25}$.

${ }^{21}$ W Zániku samoty Berhof Marek Probosz i Zbigniew Suszyński wygłaszali kwestie wyłącznie w języku niemieckim, dlatego zbędne było reżyserowanie dubbingów. Natomiast w Stinu kaparadiny ich bohaterowie mówili głosem Michala Pavlaty i Jiříego Pragera, zob. Český hraný film VI 1981-1993. Czech feature film VI 1981-1993, Národní filmový archiv, Praha 2010, s. 436.

22 Alena Bechtoldová, Miluji iluzji, proto miluji svou profesi..., „Kino” 1986, nr 14, s. 6-7.

${ }^{23}$ "Ślady wilczych zębów". Premiera nowego filmu czechosłowackiego, „Trybuna Ludu" 1985, nr 100, s. 1.

24 -ta- (Táňa Bretyšová), Zánik samoty Berhof, „Filmový přehléd” 1985, nr 3, s. 31.

${ }^{25}$ Jan Lukeš, Diagnózy času. Český a slovenský poválečný film (1945-2012), Nakladatelství Slowart, Praha 2013, s. 216. 
W tym zestawie należy zwrócić uwagę na nakręcone rok wcześniej Spotkanie z cieniem (Schi̊zka se stíny) również z Janą Brejchovą w roli głównej. W 1984 roku na festiwalu w San Remo zdobyło Grand Prix ex aequo z węgierskim Buntem Hioba (Jób lázadása) w reż. Imre Gyöngyössy'ego i Barna Kabaya oraz wpisywało się w nurt, który jeden z polskich krytyków nazwał ",sentymentalnym pacyfizmem" ${ }^{26}$. Naturalny związek tych dwóch filmów Svobody był oczywisty także dla niektórych polskich recenzentów ${ }^{27}$. W czeskich opiniach wielokrotnie podkreślano, że Svoboda jest twórca, który rozwija się z filmu na film, a Zánik samoty Berhof jest bezsprzecznie jego najlepszym dziełem ${ }^{28}$. Nie należy jednak zapominać o przekonaniach politycznych reżysera, który przy zachowaniu całkowitej twórczej niezależności był konsekwentnym komunistą ${ }^{29}$. W sposób budzący nie tylko dzisiaj mieszane uczucia, w wywiadzie udzielonym „Československemu vojákovi" zaktualizował swój filmowy przekaz:

Każdy myślący człowiek, który obserwuje niebezpieczny rozwój sytuacji międzynarodowej, a szczególnie rozmieszczanie amerykańskich rakiet w zachodniej Europie, nie może pozostać obojętny. Za rok będziemy świętowali czterdziestą rocznicę zwycięstwa nad faszyzmem. Zbrodnicze idee siłowej dominacji na świecie, stymulowane przez szowinistyczne nastroje i niebezpieczne doktryny wojenne przecież dotyczą całego świata, a on zachowuje się tak jakby owe czterdziestolecie było wystarczająco długim czasem by zapomnieć ${ }^{30}$.

Zresztą w ówczesnym dyskursie publicystycznym traktowano renesans tematyki wojennej jako konsekwencję międzynarodowych napięć, uruchomienia Reaganowskiego programu "gwiezdnych wojen", lokalnych konfliktów zbrojnych i eskalacji działań ekstremistycznych.

26 Janusz Gazda, Między kanibalizmem a sztuka. San Remo 1984, „Tygodnik Kulturalny” 1984, nr 16, s. 10.

${ }_{27}$ Na ekranach. Ślady wilczych zębów, „Nowiny” 1986, nr 287, s. 6.

${ }_{28}$ Miroslav Zůna, Zánik samoty Berhof, „Scena” 1984, nr 11, s. 5.

${ }_{29}$ Karel Steigerwald, kontrowersyjny dziennikarz i dramaturg, a jednocześnie kolega Svobody z FAMU, tak napisał o jego postawie politycznej w czasie normalizacyjnej czystki: „Kolejnym, który podlizywał się tzw. wyższym czynnikom był Jirka Svoboda. Wstąpił wtedy do partii, nie był ani aparatczykiem ani działaczem. Po prostu był członkiem partii. Nie wiadomo dlaczego w to wierzył i to nawet w roku 1989, kiedy wśród personelu praskich teatrów panowały buntownicze nastroje, on pracując na Barrandovie dopuszczał jedynie pierestrojkę pod auspicjami partii [...] ale jego filmy były przyzwoite", zob. Marie Barešova, Tereza Cz. Dvořaková, Generace normalizace. Ztracená naděje českého filmu?, Národní filmový archiv, Praha 2017, s. 181.

${ }^{30}$ Ladislava Vydrová, Filmový zápisník. Zánik samoty Berhof, "Československý voják" 1984, nr 9, s. 40-41. 
Zwracano uwagę na to, że najczęściej twórcy odwołujący się do niedawno minionej historii sami nie doświadczyli okropności przemysłu śmierci, bowiem jak Jiří Svoboda (rocznik 1945) wychowali się już po wojnie:

W tym ujęciu traktują oni owe historyczne lata nie tylko jako nieprzebrany rezerwuar ludzkich przypadków kiedy cienka była granica między życiem a śmiercią, ale jako odwołanie do istoty człowieczeństwa deformowanego przez odebranie mu podstawowych wartości, bo to przecież przynosi wojna ${ }^{31}$.

Chyba najbardziej wyraziście ideologiczna perspektywa została wyrażona w recenzji wpływowego krytyka Jana Klimenta, publikującego na łamach „Rudého Práva” - centralnego dziennika Komunistycznej Partii Czechosłowacji (KPCz). Kliment był czołowym piewcą normalizacji, tropiącym „antysocjalistyczne tendencje wśród czeskich filmowców”, a wnioski wyciągane przez niego charakteryzowały się bezkrytycznym respektowaniem linii programowej KPCz w zakresie funkcjonowania produkcji filmowej ${ }^{32}$. W omawianym przypadku wystawił obrazowi Svobody znakomitą notę, ale powiązał tematykę opowieści z tzw. zachodnioniemieckim rewanżyzmem. „Dzisiaj, gdy w sąsiadującej z nami RFN nawet czynniki rządowe bezwstydnie grożą zbrojnym odwetem, gdy w antysocjalistycznym obłędzie otwiera się na oścież drzwi neofaszyzmowi i neofaszystom głos tego filmu brzmi szczególnie alarmująco" - pisał. W dalszej części dodał jeszcze „antyhumanistyczne zaślepieniu antysowieckiego krzyżactwa”, „,bezduszne maszyny do zabijania” i oczywiście „zasługi ZSRR w utrzymaniu pokoju”. Natomiast wspólny polsko-czeski charakter produkcji został przez Klimenta dostrzeżony jedynie $\mathrm{w}$ parytetach dotyczących obsady (jego zdaniem role wilkołaków grali M. Brobosz i Z. Suzsinski) ${ }^{33}$. Svobodę jednak, mimo wcześniej cytowanych „antyimperialistycznych" deklaracji, nie interesowały proste przekazy, co można ocenić dopiero z perspektywy kilkudziesięciu lat. W połowie ubiegłej dekady Petr Koura tak podsumował znaczenie Zániku samoty Berhof:

Ten dramat czasami przypominający kino grozy artystycznymi środkami wprowadza nas w opowieść o bezmyślności wojny i przemocy. Film pokazuje równoprawne motywacje zachowań wszystkich bohaterów, co jak na normalizacyjne warunki było dość wyjątkowe ${ }^{34}$.

31 Alena Bechtoldová, Zánik samoty Berhof, „Kino” 1984, nr 6, s. 6.

32 Alena Prokopová, Eva Zaoralová, Život s filmem, Novela Bohemia, Praha 2012, s. 115.

33 Jan Kliment, Umĕni proti zániku. Významný nový film z Filmového studia Barrandov, „Rudé právo” 1985, nr 28, s. 5.

34 Petr Koura, Obraz nacistické okupace v hraném českém filmu 1945-1989, [w:] Film a dĕjiny, red. Petr Kopal, Nakladatelství Lidové noviny, Praha 2005, s. 241. 
Koprodukcyjne walory podniósł w jednej z publikacji sam Jiří Svoboda. Poza zdawkowymi, ciepłymi uwagami na temat filmowej współpracy, w których podkreślił historyczne znaczenie i obecną pozycję polskiego filmu, rolę branżowych i osobistych kontaktów z przyjaciółmi oraz partnerami znad Wisły, znalazła się też ciekawa deklaracja, którą można było potraktować jako zapowiedź nowego paradygmatu we wzajemnych celuloidowych przedsięwzięciach:

Myślę, że nasz film - oby został tylko ciepło przyjęty przez widzów - otworzy szerzej ramy polsko-czechosłowackiej współpracy filmowej. Nie chcę zapeszać, więc nie będę mówił o szczegółach, ale już niebawem kręcić będę kolejny film, w którym tym razem główną rolę kobiecą kreować będzie jedna z polskich aktorek ${ }^{35}$.

Jeszcze na etapie zdjęciowym koprodukcyjny charakter przedsięwzięcia stanowił najsilniejszą medialną podpórkę. Co ciekawe, czasami traktowano go nie tylko jako kontynuację zapoczątkowanych przez Janusza Majewskiego wspólnych filmowych projektów, lecz jako punkt odniesienia przywoływano zapomniany dziś polsko-czechosłowacki serial Dlouhá bílá stopa, rok wcześniej we współpracy z TWF Poltel wyreżyserowany przez Petra Tučka ${ }^{36}$. Zresztą autor tej korespondencji dokładnie opisał podział zadań między polskich i czeskich partnerów:

Współpraca czechosłowackich i polskich filmowców układa się bardzo dobrze. Strona czechosłowacka jako swój wkład wnosi technikę, materiał literacki, reżyserię aktorów i montaż. My natomiast partycypujemy w scenografii, dostarczeniu rekwizytów, planach zdjęciowych w Polsce, obsłudze organizacyjnej na terenie naszego kraju (większość zdjęć robiona jest po naszej stronie) oraz zespole aktorskim.

${ }^{35}$ Janusz Latoszek, W czechosłowacko-polskiej koprodukcji...

36 Jerzy Gołębiowski, Wspótpraca filmowców polskich i czechostowackich. "Zagłada Poziomkowego Dworu” w przyszłym roku na ekranach. Korespondencja wtasna "Trybuny Robotniczej” z Pragi, „Trybuna Robotnicza” 1983, nr 199, s. 6. Serial Dlouhá bílá stopa w polskiej telewizji prezentowany pod tytułem 3 plus jedna do dziś błąka się po niszowych kanałach regionalnych TVP. Ostatnio, latem 2017 roku przypomniała go w wakacyjnym paśmie TVP Poznań. W literaturze czeskiej raczej jest pomijany, a jego kariera ekranowa zakończyła się na premierowych pokazach i jednej powtórce w latach 80. XX wieku. Natomiast cieszył się dużą popularnością w telewizji zachodnioniemieckiej. Ciekawostką był w nim udział aktorów, których popularność kojarzyła się zarówno z dyskursem popularnym - sensacyjnym, jak i propagandowym: Stanisława Mikulskiego czyli filmowego agenta J-23 Hansa Klosa i Vladimíra Brabca serialowego "normalizacyjnego" majora Zemana, zob. Jiří Moc, Seriály od A do Z. Lexikon českých seriálů, Česká televize, Praha 2009, s. 43. O serialu przypomniał w 2003 roku Petr Jančárek, który w ramach cyklu czeskiej telewizji (ČT) Pokračování př́ště zrealizował półgodzinny dokument jemu poświęcony. 
Bariery językowe zostały przełamane już po pierwszym tygodniu wspólnych zdjęć-liczył się profesjonalizm, a tego nie brakowało ${ }^{37}$. Svoboda wielokrotnie podkreślał artystyczne zaangażowanie kierownictwa zespołu „Kadr" - Jerzego Kawalerowicza i Krzysztofa Teodora Toeplitza, którzy przed podjęciem rozmów nie tylko zapoznali się z powieścią Körnera, lecz także przygotowali swoje wersje modyfikacji scenariuszowych. Doceniał również, odmienne niż na Barrandovie, podejście do pracy w plenerze oraz uznanie samodzielności reżyserskiej za podstawowy komponent pracy twórczej. „Zwracam na to uwagę - mówił - gdyż w kinie czechosłowackim nie jest to praktykowane, reżyserzy trzymają się wiernie scenopisu, podporządkowując mu aktorów, scenerię, tło" ${ }^{\prime 38}$. Krzysztof Teodor Toeplitz kierownik artystyczny „Kadru” przy okazji następnego wspólnego przedsięwzięcia oświadczył, że stała współpraca z drugim zespołem Josefa Císařa, która zaowocowała powstaniem Słonej róży Janusza Majewskiego i Śladów wilczych zębów Svobody, ma doprowadzić do produkowania w przyszłości przynajmniej jednego filmu rocznie ${ }^{39}$.

Sam Jiř́ Svoboda przyznawał się do związków z dziełami z okresu nazywanego „Zlatá šedesátá" (Złote lata sześćdziesiąte) czy lepiej „Československý filmový zázrak" (Czechosłowacki cud filmowy), a w Polsce po prostu „czechosłowacką nową falą". Najchętniej porównywał Zánik samoty Berhof z filmem Františka Vláčila Małgorzata, córka Łazarza, który uznawany jest za

37 Svoboda wyjątkowo cenił sobie współpracę z drugim reżyserem A. Reiterem, kierownikiem produkcji ze strony polskiej Urszulą Orczykowską i scenografem B. Moserem „którzy odwalili kawałek solidnej roboty i w niemałej mierze przyczynili się do takiego artystycznego rezultatu", zob. Ladislava Vydrová, Filmový zápisník. Zánik samoty Berhof.

${ }^{38}$ Mówi reżyser Jiři Svoboda. Sytuacje ostateczne, rozmawiat Bogdan Zagroba, „Film” 1984, nr 44, s. 14-15.

${ }^{39}$ Krzysztof Teodor Toeplitz, Kadr, „Film” 1984, nr 27, s. 14-15. Pretekstem do sformułowania owej deklaracji było przystąpienie do produkcji filmu Pościg w reż. Stanislava Strnada, który ostatecznie wszedł na ekrany w Polsce jako List gończy, zaś w Czechach wyświetlano go pod tytułem Zátah (obława). Zresztą prasa filmowa śledziła postępy tej realizacji. W jednym z wakacyjnych numerów tygodnika „Film” poinformowano: „Zdjęcia rozpoczęły się w CSRS. We wrześniu ekipa przenosi się do Polski, na zdjęcia do Łodzi, Warszawy, Torunia i Ustki. Scenariusz napisał Jan David Novotný. Operatorem jest Josef Pavok, scenografię projektują Jakub Černý i Bożysława Chomnicka, a produkcją kierują Přemyslav Pražsky i Urszula Orczykowska”, zob. Wspólnie z Barrandovem. Pościg, „Film” 1984, nr 38, s. 2. Na łamach czeskiego „Kina” z kolei można było przeczytać: „Reżyser Stanislav Strnad nakręcił wspólnie z polską ekipą filmową trzymający w napięciu obraz kryminalny «Zátah». Sensacyjna akcja pokazuje nie tylko trudną i niebezpieczną pracę oficerów bezpieczeństwa, ale również przypadek dwóch młodych recydywistów, którzy usiłują przez Polskę udać się nielegalnie na zachód. Interesujące role stworzyli: Ladislav Potměšil, Tomáš Vacek, Jiří Kodet, Rudolf Jelínek. Razem z nimi zagrali polscy aktorzy: Stanisław Michalski, Jerzy Kryszak i Henryk Talar”, zob. (JIR), Co nového na Barrandovĕ, „Kino” 1985, nr 3, s. 2. 
jeden z czołowych filmów w całej historii kinematografii naszych południowych sąsiadów ${ }^{40}$. Związki z twórczością Vlač́la zauważył także w jednej z recenzji Pavel Melounek, choć Zánik samoty Berhof powiązał nie z Małgorzata, córką Eazarza, ale z jego dwoma innymi filmami z okresu późniejszego: Stínami horkého léta (1977) i Pasáčkem z doliny (1983). Szczególnie pierwszy z nich przynosił podobne ekranowe dylematy i napięcia między bohaterami, choć jego tłem był inny epizod z okresu powojennego - rajdy ukraińskich nacjonalistów z terenów radzieckiej Ukrainy i Polski na zachód w 1947 roku. Jednak ramy obu opowieści są wspólne - opowiadają o szaleństwie i fanatyzmie skonfrontowanym ze zwyczajnością. Zwyczajnością może nazbyt pospolita, okrutną, bo uformowaną przez surowe warunki, w jakich przyszło wieść ową egzystencję, ale przecież będącą „wysepką naturalnego porządku”:

Svoboda z Körnerem jednak nie proponuja, by ową pospolitość uznać za przeciwwagę heroizmu. Nie konfrontują tu czarnych i białych charakterów, a jedynie autochtonów otępiałych monotonnym, surowym życiem z obcymi przepojonymi fanatyczną wiarą. Tragedią tych ostatnich jest, że owa wiara okazuje się fałszywa ${ }^{41}$.

Nie było też jednoznacznych opinii branżowych. W Polsce na łamach „Sztandaru Młodych" niepodpisany recenzent opublikował przedziwny passus świadczący o jego niewielkich kompetencjach, całkowitym niezrozumieniu kontekstu i pisaniu pod ideologiczną sztancę:

Końcowy rezultat fatalny, tzw. progu metafory nie udało się przekroczyć, za to pogranicze czesko-polsko-niemieckie roku 1945 jawi się jako okolica cudaczna, zapełniona irytującymi postaciami, jakiś tatuś-psychopata, fantastyczna siostra zakonna z niemieckim odznaczeniem na szyi, dwaj "wilkołascy” nie widza, że są ścigani, o wątku erotycznym zamilczmy ${ }^{42}$.

${ }^{40}$ Współscenarzysta i autor literackiego pierwowzoru Zániku samoty Berhof Vladimír Körner wielokrotnie współpracował z Františkiem Vláčilem, który kilka razy sięgał po narracje zaczerpnięte z jego powieści, m.in. Adelheid i Údolí včel. Körner, wspominając Vlačila, napisał: „Chociaż byliśmy przyjaciółmi, realizacja każdego filmu powodowała, że dostawaliśmy się do niewoli emocji. Nie mogło być inaczej, wszak filmy Vláčila opowiadają o potrzebie ludzkiej godności, relacjach między ludźmi, okrucieństwie i oczywiście też o śmierci. To są sprawy, które człowiek głęboko skrywa w sobie i nie chce ich ujawnić", zob. Šarka Horáková, Podobenství o Františku Vláčilovi: podle Markety Lazarové, Nakladatelství XYZ, Praha 2008, s. 213.

41 Pavel Melounek, Zánik samoty Berhof, „Zábeř” 1984, nr 18, s. 6. Recenzja ta została także opublikowana po śmierci Melounka w tomie jego drobnych pism, zob. tenże, Necenzurovana zpravá o českém filmu. Nová kniha o skutečném vývoji české kinematografie, Artes Liberales, Praha 2010, s. 24.

${ }^{42}$ Filmoteka. Ślady wilczych zębów, „Sztandar Młodych” 1983, nr 252, s. 5. 
Wtórował mu autor recenzyjnej wzmianki w tygodniu "Razem”, który skrytykował skłonność Svobody do nadużywania środków wyrazu właściwych dla kina grozy, przede wszystkim kontrastowego operowania światłem i cieniem. W konsekwencji spłaszczyło to epicki wymiar opowieści, która zatraciła swój uniwersalny charakter. Zamiast niego „otrzymaliśmy mocno wydumana, naturalistyczną opowieść o ciężkiej doli córki psychopaty" 43 - czytamy na łamach tego czasopisma. Uczucie niewykorzystanej przez reżysera szansy, jaką dawał temat i scenariusz, towarzyszyło także recenzentce tygodnika „Film” Elżbiecie Dolińskiej. Znakomicie oceniła pierwszą część filmu, w której poznajemy głównych protagonistów, zaczynamy wchłaniać aurę miasteczka Kolštejn i przedzierać się przez dzikie ostępy sudeckich gór, drugą zawierającą wątek Ulryki konfrontującej swą wrażliwość z przerażającą postawą Salome i jej podopiecznych oraz przebiegłą grą porucznika, nazwała „zlekceważoną", a trzecia, z krwawym finałem - „żenującą"44.

Znacznie lepiej ocenił Ślady wilczych zębów publicysta „Trybuny Ludu” Zygmunt Wiśniewski. Jego zdaniem nasi południowi sąsiedzi posiedli umiejętność budowania dramaturgii, tworzenia atmosfery grozy i tajemniczości oraz wyraźnego i plastycznego budowania postaci w stopniu, którego powinniśmy im pozazdrościć. Nie umknęło jednak recenzentowi odwołanie się do odmiennych tradycji, co przyniosło w konsekwencji estetykę rzadko spotykaną w filmach wyłącznie polskich ${ }^{45}$.

Głosy czeskiej krytyki były zdecydowanie bardziej afirmatywne. $\mathrm{Na}$ łamach dwutygodnika „Kino” ukazały się aż dwie recenzje. Jana Bílková za niezwykle trafne uznała wprowadzenie przez Svobodę i Körnera ramy dramaturgicznej w postaci sceny niemającej swego odpowiednika w powieści-spotkania porucznika z zakonnicąSalome na posterunku w Kolštejnie oraz psychologiczne pogłębienie motywacji głównych bohaterów, głównie porucznika, któremu na ekranie poświęcono więcej miejsca niż na kartach literackiego pierwowzoru. Recenzentka dostrzegła, w przeciwieństwie do polskich krytyków, skomplikowany charakter filmowej narracji:

Jiří Svoboda i Vladimír Körner nie zadają prostych pytań i nie udzielają jednoznacznych odpowiedzi. Nie podsuwają widzowi pod nos jakichś schematów o naturze dobra i zła, o winie i karze. Jednoznacznie jedynie osądzają sytuację, która może wy-

${ }^{43}$ Marek Sadowski, Kino. Ślady wilczych zębów, „Razem” 1986, nr 4, s. 24.

${ }^{44}$ Elżbieta Dolińska, Zza bezpiecznej bariery czasu, „Film” 1986, nr 6, s. 9.

45 Zygmunt Wiśniewski, Nowe polskie filmy. Dusze wilkołaków, „Trybuna Ludu” 1986, nr 16, s. 5. 
wołać deformację w ludzkich charakterach, a wtedy zdjęcia wykraczają poza konkretny opowiadany przypadek, a stają się uniwersalną narracją ${ }^{46}$.

Recenzja Aleny Bechtoldovej ukazała się jeszcze przed premiera, stąd pozbawiona jest ładunku krytycznego. Przywoływała natomiast literacki rodowód przedsięwzięcia, odniosła się do zaproponowanej we wcześniejszym obrazie Svobody Schiozka se stiny koncepcji traumy postwojennej, omówiła dość dokładnie akcję filmu i scharakteryzowała poszczególnych bohaterów. Zdaniem publicystki, podobnie jak w zrealizowanym rok wcześniej filmie Schuizka se stíny, tak i w Śladach wilczych zębów cała historia nasycona jest ponadczasowym, podstawowym motywem miłości, która pielęgnując ogólnie uznane wartości, może wyznaczać relacje między ludźmi ${ }^{47}$.

Najwnikliwszą recenzję zamieścił na łamach miesięcznika „Film a doba" Milan Hanuš. Jego szczegółowe odniesienia dotyczą kompozycji dramaturgicznej, umiejętności tworzenia nastroju, a przede wszystkim psychologicznej wiwisekcji, którą przeprowadza na swoich bohaterach i to niemal wszystkich - od głównych postaci, takich jak Salome, Unkas, Detlev i Ulryka, po drugoplanowe czy wręcz epizodyczne, jak Florian (w tej roli znakomity jako autochton polskiego pochodzenia Jerzy Nowak) czy posterunkowy Łasica ${ }^{48}$.

Zánik samoty Berhof doskonale się sprawdził w przestrzeni festiwalowej. Na XXII Festiwalu Czeskich i Słowackich Filmów w Bańskiej Bystrzycy w roku 1984 otrzymał Nagrodę Specjalną. W tym samym roku zdobył podobne trofeum z MFF w Karlowych Warach. Spodobał się także na XIX Międzynarodowych Spotkaniach Filmu i Młodzieży w Cannes, gdzie został uhonorowany nagrodami: jury młodzieżowego i publiczności, a tryumfalny pochód zamknął ponownie Nagrodą Specjalna, tym razem na Filmowym Festiwalu Ludzi Pracy 1985 - ważnej imprezie z propagandowego punktu widzenia ${ }^{49}$. Z pokazem konkursowym w Karlowych Warach wiąże się anegdota, która może posłużyć za zwieńczenie niniejszego tekstu. Scenarzysta filmu Vladimír Körner chętnie ją przywoływał przy okazji rozmaitych wywiadów:

Gdy tylko telewizyjni decydenci ustalili, że jestem w delegacji, postanowili nie transmitować uroczystości. Ale Kawalerowicz powiedział „uspokój się, my to pokażemy jako film polski". Organizatorzy nas ignorowali, nawet nie podano wody

46 Jana Bílková, Zánik samoty Berhof.

47 Alena Bechtoldová, Zánik samoty Berhof.

48 Milan Hanuš, Filmové drama vypjatých poloh, „Film a doba” 1984, nr 11, s. 641.

${ }^{49}$ Ocenění našich filmův zahraničí, „Kino” 1985, nr 5, s. 2. 
dla przepłukania gardła. Wielu twórców po prostu bało się stanąć ze mną na scenie. A tymczasem pojawił się mężczyzna w garniturze śliwkowego koloru - jak się okazało autentyczny generał KGB, akurat odpoczywający w karlowarskim sanatorium. Zobaczył Kawalerowicza i pocałował go w rękę - dlatego, że był znajomym jego ojca, byłego wileńskiego rabina. I ci wszyscy pieprzeni funkcjonariusze pochylili się do tej ręki jak do relikwii ${ }^{50}$.

\section{Bibliografia}

\section{Druki zwarte}

Barešova Marie, Dvořaková Tereza Cz., Generace normalizace. Ztracená naděje českého filmu?, Národní filmový archiv, Praha 2017.

Bartošková Šárka, Bartošek Luboš, Filmové profilý. Českoslovenští scenáristé, režisérii, kameramani, hudebni skladatelé a architekti hraných filmů, Československý filmový ústav, Praha 1986.

Biddiscombe Peter, Werwolf. Brunatni pogrobowcy Hitlera, przeł. Sławomir Kędzierski, Wydawnictwo Czerwone i Czarne, Warszawa 2013.

Čermáková Dana, Karel Roden, Nakladatelství Imagination of People, Praha 2013.

Český hraný film VI 1981-1993. Czech feature film VI 1981-1993, Národní filmový archiv, Praha 2010.

Fikejz Miloš, Český film. Herci a herečky / I. díl: A-K, Nakladatelství Libri, Praha 2006.

Herz Juraj, Autopsie (pitva režiséra), Mladá fronta, Praha 2015.

Horáková Šarka, Podobenství o Františku Vláčilovi: podle Markety Lazarové, Nakladatelství XYZ, Praha 2008.

Körner Vladimír, Rozhovory 1964-2009, Nakladatelství Dauphin, Praha 2009.

Körner Vladimír, Zagłada Poziomkowego Dworu, przeł. Andrzej Piotrowski, Wydawnictwo Czytelnik, Warszawa 1976.

Koura Petr, Obraz nacistické okupace v hraném českém filmu 1945-1989, [w:] Film a dĕjiny, red. Petr Kopal, Nakladatelství Lidové noviny, Praha 2005.

Lukeš Jan, Diagnózy času. Český a slovenský poválečný film (1945-2012), Nakladatelství Slowart, Praha 2013.

Majewski Piotr M., „Niemcy sudeccy” 1848-1948. Historia pewnego nacjonalizmu, Wydawnictwa Uniwersytetu Warszawskiego, Warszawa 2007.

Martinek Libor, Kwestia czesko-niemiecka w adaptacjach filmowych dzieł literackich Vladimíra Körnera (z języka czeskiego przełożyli Leszek Engelking i Elżbieta Wandycz), [w:] Przyszłość w kinie Europy Środkowej i Wschodniej po roku 1989. Zbiór materiałów z konferencji 8-10 listopada 2007 roku w Poznaniu, red. Bogusława Bakuła, Monika Talarczyk-Gubała, Wydawnictwo WiS, Poznań 2008.

Melounek Pavel, Necenzurovana zpravá o českém filmu. Nová kniha o skutečném vývoji české kinematografie, Artes Liberales, Praha 2010.

50 Starý vlk loví sám. Rozhovor s Vladimírem Körnerem, připravíli Michal Jareš a Lubor Kasal, „Tvař” 2006, nr 6, s. 5. 
Moc Jiří, Seriály od A do Z. Lexikon českých seriálů, Česká televize, Praha 2009.

Prokopová Alena, Eva Zaoralová, Život s filmem, Novela bohemica, Praha 2012.

Remešová Michalina, Schuster Roman, Jana Brejchová otveřenĕ: Lásky mé, já stůn̆u! Strhující životní př́beh nejkrásnější české herečky a jejích mužů, Fany, Praha 2014.

Šteflová Adriana, Jana Brejchová, Nakladatelství Bondy, Praha 2014.

Tarajło-Lipowska Zofia, Historia literatury czeskiej, Zakład Narodowy im. Ossolińskich, Wrocław 2010.

\section{Czasopisma}

(JIR), Co nového na Barrandovĕ, „Kino” 1985, nr 3.

Albuk (Alojzy Bukolt), W kinie. Ślady wilczych zębów, „Gazeta Pomorska” 1986, nr 8.

Awar, [Edwarda Opoczyńska], Recenzje. Zagłada Poziomkowego Dworu, „Wiadomości” 1977, nr 11.

B. Z. (Bogdan Zagroba), Wehrwolf znaczy "wilkołak". O realizacji czechosłowacko-polskiego filmu "Zagłada Poziomkowego Dworu”, „Film” 1984, nr 10.

Bechtoldová Alena, Zánik samoty Berhof, „Kino” 1984, nr 6.

Bechtoldová Alena, Miluji iluzji, proto miluji svou profesi..., „Kino” 1986, nr 14.

Bílková Jana, Zánik samoty Berhof, „Kino” 1985, nr 5.

Bluszcz Anna, Zagłada Poziomkowego Dworu, „Głos Ludu” 1979, nr 138.

Dolińska Elżbieta, Zza bezpiecznej bariery czasu, „Film” 1986, nr 6.

Filmoteka. Ślady wilczych zębów, „Sztandar Młodych” 1983, nr 252.

Gazda Janusz, Między kanibalizmem a sztuka. San Remo 1984, „Tygodnik Kulturalny” 1984, nr 16.

Gołębiowski Jerzy, Wspótpraca filmowców polskich i czechosłowackich. "Zagłada Poziomkowego Dworu" w przyszłym roku na ekranach. Korespondencja własna "Trybuny Robotniczej" z Pragi, „Trybuna Robotnicza” 1983, nr 199.

Hanuš Milan, Filmové drama vypjatých poloh, „Film a doba” 1984, nr 11.

Hejčová Helena, Variace na jedno téma /hovořime se scenařistou Vladímirem Körnerem/, „Kino” 1984, nr 16.

J. B., Mały przewodnik kinomana, „Tygodnik Demokratyczny” 1986, nr 50.

Kliment Jan, Umĕni proti zániku. Významný nový film z Filmového studia Barrandov, „Rudé právo" 1985, nr 28.

Körner Vladimír, Svoboda Jiří, Zánik samoty Berhof [ukázka ze scénaře], „Film a doba” 1984, nr 2.

Kronika kulturalna, „Tak i Nie” 1984, nr 18.

Latoszek Janusz, W czechosłowacko-polskiej koprodukcji. Na planie: "Zagłada Poziomkowego Dworu", "Życie Warszawy" 1983, nr 229.

Mam mało czasu, czyli spotkanie z Markiem Proboszem, notowała Ilona Łepkowska, „Film” 1984, nr 18.

Melounek Pavel, Zánik samoty Berhof, "Zábeř" 1984, nr 18.

Mówi reżyser Jiř́ Svoboda. Sytuacje ostateczne, rozmawiał Bogdan Zagroba, „Film” 1984, nr 44.

Na ekranach. Ślady wilczych zębów, „Nowiny” 1986, nr 287.

Ocenění našich filmův zahraničí, „Kino” 1985, nr 5.

Sadowski Marek, Kino. Ślady wilczych zębów, „Razem” 1986, nr 4.

Starý vlk loví sám. Rozhovor s Vladimírem Körnerem, připravíli Michal Jareš a Lubor Kasal, „Tvař” 2006, nr 6. 
Ślady wilczych zębów (opracował hs), „Filmowy Serwis Prasowy” 1985, nr 6.

Ślady wilczych zębów, „Film” 1985, nr 39.

"Ślady wilczych zębów". Premiera nowego filmu czechostowackiego, „Trybuna Ludu” 1985, nr 100.

-ta- (Táňa Bretyšová), Zánik samoty Berhof, „Filmový přehléd” 1985, nr 3.

Toeplitz Krzysztof Teodor, Kadr, „Film” 1984, nr 27.

Vydrová Ladislava, Filmový zápisník. Zánik samoty Berhof, „Československý voják” 1984, nr 9.

Walc Jan, Małe recenzje. Zagłada Poziomkowego Dworu, „Literatura na Świecie” 1977, nr 6.

Wiśniewski Zygmunt, Nowe polskie filmy. Dusze wilkołaków, „Trybuna Ludu” 1986, nr 16.

Wspólnie z Barrandovem. Pościg, „Film” 1984, nr 38, s. 2.

Wspólnie z Czechami. Zagłada Poziomkowego Dworu, „Film” 1983, nr 48.

Zůna Miroslav, Zánik samoty Berhof, „Scena” 1984, nr 11.

\section{Streszczenie}

Polsko-czechosłowackie inicjatywy filmowe kilkakrotnie wykorzystywały prozę Vladimíra Körnera. Po raz pierwszy uczynił to w roku 1982 Jiří Svoboda, ekranizując jego minipowieść Zánik samoty Berhof, która w polskich kinach była prezentowana pod tytułem Ślady wilczych zębów. Akcja zarówno filmu, jak i powieści rozgrywa się na pograniczu polsko-czechosłowacko-niemieckim jesienią 1945 roku, kiedy nowa rzeczywistość jeszcze się nie uformowała, a stara nie odeszła w zapomnienie. Svoboda znakomicie zbudował atmosferę niemal gotyckiej grozy i pokazał niejednoznaczne postawy ludzkie w obliczy zagrożenia. Zdjęcia kręcone były w Czechach i w Polsce, zaś obok słowackiego aktora Milana Kňažki i czeskiej gwiazdy Jany Brejchovéj wystąpili także polscy wykonawcy, m.in. Marek Probosz i Zbigniew Suszyński. 